\title{
RESEARCH AND TEACHING IN PORTUGUESE FOR SPECIFIC PURPOSES
}

\author{
Karina Veronica Molsing (Pontifícia Universidade Católica do Rio Grande do Sul) \\ CRISTINA BECKER LOPES-PERnA (Pontifícia Universidade Católica do Rio Grande do Sul)
}

\section{Introduction}

This collection of papers represents the inaugural edition of the Brazilian English Language Teaching + Journal focused on the theme of Portuguese as an Additional Language. To commemorate the inclusion of this new feature of BELT, we present an overview of Portuguese as an Additional Language in Brazil and at the Pontifícia Universidade Católica do Rio Grande do Sul (PUCRS ${ }^{1}$ ). Moreover, we discuss the founding of Portuguese for Academic Purposes as a new area of research with repercussions for how we approach Portuguese for foreigners in academic contexts on the institutional, pedagogical as well as linguistic levels. With this discussion, we hope to encourage further research in this area such that we may accommodate the increasing foreign demand on Brazilian institutions.

\section{Portuguese as an Additional Language in Brazil}

Due to the Science without Borders Program ${ }^{2}$, a government initiative that has fomented the education of Brazilian scholars in top universities and research institutions outside of Brazil, there has been a major movement towards the accelerated acquisition of the English language. Though there have been open calls for a variety of countries in which the native language is not English, this language is still being treated as the lingua franca of academic activities. As such, there has been increasing interest in English preparatory courses, in addition to the already consistently high pursuit.

On the other hand, considering the global focus on Brazil in socioeconomic, political and cultural terms, there has also been a significant increase in incoming foreigners in Brazilian institutions. This is particularly true in higher education, where international institutions and organizations have pursued cooperative agreements in all academic areas with Brazilian higher education institutions (HEIs). As a result, the Portuguese language has become increasingly valued as an object of educational, methodological and scientific activities, with a corresponding increase in conferences and seminars outside of Brazil and Portugal focused on this language.

In the broad area of Linguistics, Portuguese, in both European and Brazilian varieties, has become one of the most-studied "understudied" languages in comparative linguistics, considering all theoretical areas - syntax, semantics, pragmatics and phonology - as well as applied areas such as discourse or education policy. A quick browse on Linguist List ${ }^{3}$ proves that there has been an increasing number of journals, books and events dedicated to the study of the Portuguese language and the dissemination of the results. Henceforth, Portuguese as an Additional Language (PAL) has become a viable area for teaching and learning practices as well research, both in and out of Portuguesespeaking countries.

\section{The current state of PAL in Brazil}

Now, in addition to Science without Borders, which had concurrently inaugurated the English without Borders Program, the Languages without Borders Program ${ }^{4}$ has been launched, providing courses for French, Spanish, Italian, Japanese, Mandarin, German and Portuguese for foreigners. The

\footnotetext{
1 WWW.pucrs.br

2 www.cienciasemfronteiras.gov.br

${ }^{3}$ A "web site for [...] professional communication and networking for the world-wide community of linguists", www.linguistlist.org.

${ }^{4}$ http://isf.mec.gov.br/

BELT Journal • Porto Alegre • v.5 • n.2 • p. 1-7 • julho/dezembro 2014 
objective of this expanded program is to prepare students to attend those universities in which the higher education courses are taught in a language other than English. Moreover, the program addresses the needs of Brazilian university programs, which have been receiving greater numbers of foreign professors and students on their campuses. This includes the offer of distance and on-campus courses as well as the application of proficiency tests. In sum, these joint programs are part of a greater movement towards internationalizing higher education and scientific advancement with ultimate benefits for Brazilian progress. They are also a reflection of the greater social reality in Brazil in which there is an overall greater demand for Brazilian culture and language.

While all federal universities in Brazil provide access to these programs, the number of Portuguese language programs aimed at foreigners has grown at an exponential rate in private universities as well. Moreover, informal language schools, a commonplace presence all over Brazil, which has always had English as its frontrunner, have now been offering more and more Portuguese for foreigners courses, sometimes exclusively in order to keep up with demand.

With respect to government-recognized proficiency exams for Brazilian Portuguese (BP), today, there is only one exam, designed by the Ministry of Education and the Anísio Teixeira National Institute for Educational Studies and Research, aimed at evaluating BP proficiency. The proficiency certificate in the Portuguese language for foreigners (Celpe-Bras ${ }^{5}$, in Portuguese) "is accepted by companies and higher education institutions as proof of competence in the Portuguese language and, in Brazil, it is required by universities for entrance purposes in undergraduate and graduate programs" (translation ours ${ }^{6}$, MEC/INEP 2013).

\section{The current state of PAL at PUCRS}

PUCRS, a private university, has also seen an increasing demand in the number of requests for customized Portuguese for foreigners courses in a variety of modalities. The number of foreign students and professors at PUCRS has been increasing rapidly while the institutional, educational and research initiatives have only recently been able to adequately attend to these needs. Moreover, the increased interest in studying and working at PUCRS (as with other Brazilian institutions) is frequently greater than the respective proficiency in BP, which leads to difficulties in the daily routine of these scholars in academic contexts. PUCRS has reacted by increasing the number of courses provided at both undergraduate and graduate levels, while in-house professors have been dedicating efforts towards improving the teaching and learning processes of the Portuguese language. Current practices include the inauguration of the LEXIS Language Center, aimed at attending to the needs of the PUCRS community, as well as populations in Porto Alegre and surrounding regions.

In addition to regular semester courses, foreign institutional partners of PUCRS have been requesting short-term courses, varying between two weeks to one month. In the past few years, extracurricular courses were organized for partners such as Harvard University, the University of Washington and the National University of Singapore. There have also been requests for courses for individuals, international representatives of strategic partners, universities and companies.

As a result, in addition to institutional and educational actions, we see the need to establish and develop an area of research dedicated to Portuguese for Academic Purposes, with primary relevance for the growing population of foreigners in the PUCRS community, as well as for native speakers with respect to teacher development. While there has been research involving academic aspects or contexts, specifically academic purposes has been a secondary or accidental objective.

To address this gap, we have founded a research group whose main focus is to begin to address the specific linguistic needs of non-native learners of Portuguese as an additional language ${ }^{7}$. The initial results of some of this research have been presented in international conferences in which the feedback received from the international academic field suggests an expectation of progress which implies the need to increase the scope of linguistic research using theories of language acquisition and use.

\footnotetext{
${ }^{5}$ http://portal.inep.gov.br/celpebras

${ }^{6}$ Original text: "Celpe-Bras é aceito em firmas e instituições de ensino como comprovação de competência na língua portuguesa e, no Brasil, é exigido pelas universidades para ingresso em cursos de graduação e em programas de pós-graduação."

The term 'additional language' will be used interchangeably with the abbreviations for second language (L2), third language (L3), etc.
}

BELT Journal $\bullet$ Porto Alegre $・$ v.5 $・$ n.2 $・$ p. 1-7 $\bullet$ julho/dezembro 2014 


\section{Brazilian Portuguese for Academic Purposes}

The area of teaching additional languages in the academic environment has been increasing over the past few years, including the research in this area, due to the rapid increase in interest in cultural, social and educational programs in Brazil and abroad. Consequently, the higher education institutions in Brazil have been including the commitment to creating and disseminating additional language courses, mainly for English and Portuguese, in their missions of internationalization.

Due to these changes, it is necessary that the teaching and learning process of these languages become more specialized according to the specific purposes for which the language will be used. This specialization has been observed in teaching languages such as English, whose demand is of a global nature and attends to all types of contexts. In fact, there is a well-established area called English for Specific Purposes (ESP) in which the language teaching is centered on the needs of the learner, such as, for example, English for Business, Instrumental English and English for Academic Purposes, among others. The reason for the existence of these specializations is that the proficiency in one register of English may not necessarily correspond to proficiency in some other register of English. For example, studies have shown that advanced conversational proficiency in a language does not guarantee success in the academic environment of the same language (Cummins 2000).

Since Portuguese for Academic Purposes (PAP) has not yet been fully established in the literature as a focus of research, we have adopted, for the time being, similar theoretical constructs as those that guide the research in the area of ESP, making specific adaptations for the Portuguese language, Brazilian culture and the reality of Brazilian higher education. ESP addresses communicative competencies necessary for studying in formal educational systems (Jordan 1997). This definition is broad enough to include all kinds of academic contexts on all academic levels.

By considering all the challenges faced by non-native speakers in academic contexts, it is necessary, at first, to define what is special about languages in academic contexts. For English, the research is far more advanced than for Portuguese. Therefore, academic Portuguese needs to be analyzed as it is used by native speakers in Brazil. This way, we will have a point of comparison for a posterior analysis of academic Portuguese by non-native speakers. This will result in the adequate resources for examining the needs of foreign speakers of Portuguese in the scope of higher education. This needs analysis may have repercussions in teaching BP as well as in the elaboration of proficiency exams for students who wish to attend courses at PUCRS, as well as exchange and full-time foreign students.

To begin with, differently from written academic English, written academic Portuguese can be "characterized as semantically richer, more nuanced, more flexible and better able to express subjectivity and sentiment (or negatively, as overly complex, elaborate, longwinded and subjective)" (Bennett 2010, p. $22^{8}$ ). Based on a corpus study, Bennett (2010), reports a study which describes academic Portuguese through a set of distinctive discourse features, such as, for example, the use of gerunds, sentences without verbs, among other linguistic devices. As such, by addressing the acquisition of Portuguese for academic purposes by non-native speakers, specific research is necessary in order to contemplate more than just general communicative competence.

\section{Research Group on the Use and Processing of Additional Languages}

The main objective of this research group, coordinated by Professor Cristina Becker Lopes Perna, is to establish a tradition of linguistic investigations focused on Portuguese for Academic Purposes. More specifically, our objective is to analyze language patterns used for academic purposes in BP via linguistic theory based on studies of written and oral corpora taken from native Brazilian undergraduate student and professor productions. Consequently, we aim to develop educational practices in PAP courses based on linguistic research. These practices range from the analysis of existing textbooks, the development of class plans and activities to the elaboration of methods for assessing specifically academic linguistic competence of foreign students in Brazil.

\footnotetext{
${ }^{8}$ Though this characterization is aimed at the European variety of Portuguese, the same can be said of the Brazilian variety as well.

${ }^{9}$ In Portuguese: Grupo de Pesquisa sobre o Uso e Processamento de Língua Adicional (UPLA). For details in Portuguese, see http://dgp.cnpq.br/dgp/espelhogrupo/0705653235733182.
} 
The class materials often used in Portuguese for foreigners courses follow traditional methodologies of language acquisition, that is, content-based (Brinton 2003) and task-based (Ellis 2003) approaches. Though the objective of these approaches is to develop and improve the competence of the learner, we need to have an understanding of genres in order to begin attending to the specific needs of foreign university students in Brazilian higher education institutions. As such, our research group engages in investigations involving one of the following areas: (i) collecting written and oral corpora; (ii) analyzing grammatical structures based on linguistic theories applied to the naturalistic data in the corpora; (iii) developing class plans and activities; (iv) teaching and assessing foreign students of PUCRS courses.

The researcher Douglas Biber (2004, 2006, 2007), together with other authors, emphasizes the role of corpora in the investigation of academic language, in addition to language teaching. There is research on existing corpora for English that are frequently used for language teaching purposes, such as the International Corpus of Learner English (Granger 2003) and the Michigan Corpus of Academic Spoken English (Simpson et al. 2002). These corpora, among others, generate many research projects as well as teaching and assessment materials. Our research group proposes to follow the same tradition for the Portuguese language with corresponding advancements for the education of students and professors.

The focus of these studies can be on linguistic structures in their syntactic, semantic and/or pragmatic aspects. Based on this and other studies, the results of the linguistic analyses will then be applied to the elaboration of classroom activities. This movement from corpus-based linguistic studies to the classroom is not direct or obvious. To tackle this issue, we follow the research outlined in O'Keeffe et al. (2007) and Walsh (2010), among others.

For teaching English as an additional language, there are grammars and dictionaries based on corpus research that help learners dominate subtle aspects of English. Corpus-based linguistic analyses form the foundation for textbooks such as Focus on Vocabulary (Schmitt and Schmitt 2005), which uses the Academic Word List (Coxhead 2000), as the starting point for choosing vocabulary. In sum, these types of studies present information which help to form a basis for instruction and suggest how some features of language can be taught.

Walsh (2010) claims that the amount of textbooks available enables the collection of the ideal type of data to help the teacher create materials for language teaching. These materials can address new words, linking expressions, discourse markers, grammatical structures and constructions specific to genres. Consequently, corpora can maximize the learning potential of the materials.

Previous and ongoing studies from UPLA include the following, all focused on academic writing: the pronominal system (Molsing and Perna 2013), adjectives (master's thesis by Beatriz Moro, 2014), noun phrases (final-stage doctoral study by Sheila Nunes), hedges and hedging strategies in L3 Portuguese (master's thesis and final-stage doctoral study by Sun Yuqi), complex sentences (undergraduate thesis by Marcelo Alves Soares) and metaphors (master's study in progress by Leticia Presotto). Future studies aim to include results from oral academic corpora.

In sum, the types of investigations proposed by our research group intend to contribute to the emerging tradition of research, teaching and learning and evaluation in the area of Portuguese for Academic Purposes. The results of this kind of research would offer universities the improved capacity to receive foreigners in our higher education institutions and resources to disseminate this capacity in Brazil and abroad, thus contributing to the internationalization of higher education in Brazil.

Finally, it is with great pleasure that we dedicate a portion of the scope of the BELT Journal to studies aimed at Portuguese as an Additional Language, such that we may further contribute to this area by highlighting the quality research that is being carried out in Brazil and around the world.

\section{The articles in this edition}

The first article, "Why do Chinese learners produce the expression 'de fato' in Portuguese so frequently?", was written by Sun Yuqi, a Chinese graduate student at PUCRS, whose main line of research is hedges and hedging strategies in Chinese, English and Portuguese. Here, she presents a study that originated from informal observations by Brazilian professors of Chinese students, mainly that the students appeared to produce the discourse marker "de fato" (in English, in fact or actually) at a much higher rate than native BP speakers. To address this observation in a principled way, Sun 
analyzed a series of Portuguese and Portuguese-Chinese dictionaries as well as the previous literature on the subject. Upon compiling an academic corpus of Brazilian and Chinese student productions, the author created a pragmatic classification of the uses of "de fato" and consequently proposed a contrastive analysis. Sun confirmed the more frequent use of this term by Chinese students, but, more interestingly, and perhaps the reason for which their usage caught the attention of Brazilian professors is the finding that Chinese students employed distinct pragmatic strategies for using the term when compared to native BP speakers.

Aside from the linguistic feature analyzed, Sun's research sheds light on the fact that relations between China and Brazil have been growing on all levels of society, particularly with regards to higher education and, specifically, to learning Portuguese as an additional language. This is reflected by the fact that higher education Portuguese programs have increased fivefold and student enrolment in these courses has increased almost 900 percent. Moreover, many Chinese universities have mobility programs with Brazilian institutions, an experience that the author herself took advantage of, in addition to completing her master's and doctorate studies at PUCRS.

The second article, by Lia Abrantes Antunes Soares, is entitled "O fenômeno pausa como pista para avaliação de fluência em português do Brasil como segunda língua" (Pause phenomena as a clue to evaluating fluency in Brazilian Portuguese as a second language). In this paper, Soares presents a study on how levels of fluency can be determined, at least in part, by the phenomenon of pausing. It is safe to say that very little research has been done in the way of prosody in BP, especially with respect to its application to L2 acquisition. Pausing is important because it can clue us in to how native as well as non-native speakers manage their oral discourse. As such, not all kinds of pauses are indicative of non-nativeness, though the way in which pauses are applied over the course of one's speech potentially reveals levels of fluency.

Based on BP narratives produced by native speakers of English, Soares found that two specific parameters relating to pausing were direct reflections of fluency level. One parameter is related to pauses for modifying one's utterance, while the other is related to restarting an utterance. Furthermore, the author believes that given the fact that these types of parameters are already used to measure fluency, though in an informal matter, this analysis provides a systematic, measurable and refutable way to support professional intuitions. This is a case in which a deep understanding of prosody, in all of its manifestations, can contribute to L2 studies on at least two different levels: i) an applied linguistic understanding of prosody and L2 oral fluency, with a focus on BP, and ii) a practical methodological tool for developing oral assessments.

Idalena Oliveira Chaves, in the article "Vocabulário e ortografia no ensino de português como língua adicional para coreanos" (Vocabulary and spelling in teaching Portuguese as an additional language for Koreans), presents a proposal for teaching spelling and vocabulary based on her experience teaching Portuguese to native speakers of Korean at Hankuk University in South Korea. The author's proposal takes into account the fact that Korean students must learn an entirely new alphabet when acquiring Portuguese, as well as their resulting difficulties with certain sounds and letters. Given the scarcity of studies with this particular focus, the author begins with a needs analysis of the students involved, which involves aspects such as accents and their corresponding sounds in Portuguese that do not exist in Korean, as well as inadequate use of vocabulary, among other issues. Chaves illustrates some of these difficulties with passages from student productions. To address these difficulties, Chaves proposes crossword puzzles as a means of practicing the specific issues that Korean students face when learning Portuguese spelling and vocabulary. Furthermore, this game is used as a tool for translating between the languages in question.

Finally, this edition includes a review by Rafael Marcos Tort Peixoto of the book "O Jeito que a gente diz: combinações consagradas em inglês e português" (The way we say things: well-established combinations in English and Portuguese), in its 2013 edition, authored by Stella E. O. Tagnin. Peixoto presents the book in its apparent role as a kind of resource book for translators, thus bridging the theory-practice gap to an extent. The book touches on topics that are often problematic for translators, such as idiomatic expressions, collocations and conversation markers. These issues are addressed with a perspective from corpus linguistics while illustrating with data from languages such as English, Portuguese, German, Spanish, French and Italian. 


\section{Acknowledgements}

We would like to thank the authors for their interest in participating in this inaugural edition with a focus on Portuguese as an Additional Language within the refreshed framework of the Brazilian English Language Teaching Journal, BELT+. We look forward to this edition marking the beginning of a long-standing and fruitful exchange of ideas with researchers, professionals and other academics from around the world. Moreover, we hope our readers enjoy reading this stimulating collection of papers.

Happy Holidays!

Cristina Becker Lopes Perna

Karina Veronica Molsing

Yadhurany dos Santos Ramos

Editors of BELT

\section{References}

Bennett, K. 2010. Academic discourse in Portugal: a whole different ballgame? Journal of English for Academic Purposes 9 (1), pg. 21-32.

Biber, D. 2006. Stance in spoken and written university registers. Journal of English for Academic Purposes 5, pg. 97-116.

Biber, D. \& Barbieri, F. 2007. Lexical bundles in university spoken and written registers. English for Specific Purposes 26, pg. 263-86.

Biber, D., E. Csomay, J.K. Jones, \& C. Keck. 2004. A corpus linguistic investigation of vocabularybased discourse units in university registers. In U. Connor \& T. A. Upton (Eds.) Applied Corpus Linguistics: A Multi-Dimensional Perspective. Amsterdam: Rodopi, pg. 53-72.

Brinton, D. 2003. Content-based instruction. In D. Nunan (Ed.) Practical English language teaching. New York: McGraw Hill, pg. 199-224.

Coxhead, A. 2000. A new academic word list. TESOL Quarterly 34, pg. 213-238.

Cummins, J. 2000. Putting language proficiency in its place: Responding to critiques of the conversational/academic language distinction. In J. Cenoz \& U. Jessner (Eds.) English in Europe: The acquisition of a third language. Clevedon: Multilingual Matters.

Ellis, R. 2003. Task-based language learning and teaching. Oxford: Oxford Applied Linguistics.

Granger, S. 2003. International Corpus of Learner English. http://www.uclouvain.be/en-ceclicle.html. Accessed in December 2014.

Jordan, R. 1997. English for academic purposes: a guide and resource book for teachers. Cambridge: Cambridge University Press.

Ministério da Educação. Celpe-Bras. http://portal.mec.gov.br/index.php?option=com_content\&view=article\&id=12270\&ativo=519\&Item id=518. Accessed in December 2014.

Molsing, K. \& Perna, C. 2013. The pronominal use of -se in Brazilian Portuguese academic writing. Unpublished manuscript.

Moro, B. I. 2014. Advérbios de posicionamento em textos escritos de português acadêmico. Dissertação de Mestrado, PUCRS.

O'Keeffe, A. McCarthy, M. \& Carter, R. 2007. From corpus to classroom: language use and language teaching. Cambridge: Cambridge University Press.

Schmitt, D. \& Schmitt, N. 2005. Focus on vocabulary: Mastering the academic word list. Upper Saddle River: Pearson PLC. 
Simpson, R. C., S. L. Briggs, J. Ovens, \& J. M. Swales. 2002. The Michigan corpus of academic spoken English. Ann Arbor, MI: The Regents of the University of Michigan.

Tagnin, S. E. O. 2013. O jeito que a gente diz - combinações consagradas em inglês e português. Barueri, SP: Disal Editora.

Walsh, S. 2010. What features of spoken and written corpora can be exploited in creating language teaching materials and syllabuses? In A. O'Keeffe \& M. McCarthy (Eds.) The Routledge handbook of corpus linguistics. Abingdon: Routledge, pg. 333-344. 